\title{
Genetic basis and biotechnological manipulation of sexual dimorphism and sex determination in fish
}

\author{
MEI Jie ${ }^{2} \&$ GUI Jian-Fang ${ }^{1,2^{*}}$ \\ ${ }^{1}$ State Key Laboratory of Freshwater Ecology and Biotechnology, Institute of Hydrobiology, Chinese Academy of Sciences, University of the \\ Chinese Academy of Sciences, Wuhan 430072, China; \\ ${ }^{2}$ College of Fisheries, Key Laboratory of Freshwater Animal Breeding, Ministry of Agriculture, Freshwater Aquaculture Collaborative \\ Innovation Center of Hubei Province, Huazhong Agricultural University, Wuhan 430070, China
}

Received August 22, 2014; accepted September 28, 2014; published online January 5, 2015

\begin{abstract}
Aquaculture has made an enormous contribution to the world food production, especially to the sustainable supply of animal proteins. The utility of diverse reproduction strategies in fish, such as the exploiting use of unisexual gynogenesis, has created a typical case of fish genetic breeding. A number of fish species show substantial sexual dimorphism that is closely linked to multiple economic traits including growth rate and body size, and the efficient development of sex-linked genetic markers and sex control biotechnologies has provided significant approaches to increase the production and value for commercial purposes. Along with the rapid development of genomics and molecular genetic techniques, the genetic basis of sexual dimorphism has been gradually deciphered, and great progress has been made in the mechanisms of fish sex determination and identification of sex-determining genes. This review summarizes the progress to provide some directive and objective thinking for further research in this field.
\end{abstract}

reproduction strategies, sexual dimorphism, sex determination, sex-determining gene, sex chromosome, sex control breeding

Citation: $\quad$ Mei J, Gui JF. Genetic basis and biotechnological manipulation of sexual dimorphism and sex determination in fish. Sci China Life Sci, 2015, 58: 124-136, doi: 10.1007/s11427-014-4797-9

For a long time, sex is always one of the important propositions in life sciences, because most vertebrates are gonochoristic and show significant sexual differences in morphology and physiology, which makes life more complex and wonderful and promotes some evolutionary biologists to believe "sex is the queen of problems in evolutionary biology" [1]. Since the phenomenon of hermaphrodite and sex reversal in rice field eel (Monopterus albus) was firstly reported by famous fish biologist Liu Jian-Kang in 1944 [2], which opened a fresh field for research into fish sex mechanism [3], a large number of significant achievements had been obtained in basic studies on fish sex and the related

*Corresponding author (email: jfgui@ihb.ac.cn) fields, and applied to the aquaculture practice [4]. Fishes are the most species-rich group of vertebrates with nearly half of all extant vertebrate species, which serve as an evolutionary link between invertebrates and higher vertebrates [5], so that the studies on genetic basis and mechanisms for sexual dimorphism and sex determination have been extensively noticed, and some significant progress, especially in identification of sex chromosomes and sex determination genes, has been achieved [6-8].

According to the UN Food and Agriculture Organization (FAO) (2014), world fish food supply has outpaced global population growth during the last five decades, and the aquaculture fishes have become an important animal protein source for most of the world's population [9]. Since the 
entry of the 21st century, a global consensus on effect and contribution of aquaculture to world fish supplies has emerged [10,11], and significant breakthroughs have resulted from the basic and applied studies on sex control breeding biotechnologies for sexual dimorphism [12,13]. Here, we will review recent breakthrough advancements in the studies on genetic basis and regulation mechanism of fish sexual dimorphism and sex determination, introduce several successful cases of biotechnological manipulations for sex control breeding, and thereby look forward to the promising prospects for future research in the field.

\section{Diversity of fish reproduction strategies and their application in genetic breeding}

\subsection{Diversity of reproduction strategies in fish}

Fish is the most abundant and successful group of vertebrates in the world, with about 32,700 documented species (www.fishbase.org). As primitive vertebrates, their reproduction strategies have evolved high particularities and abundant diversities to adapt to water environment change in the habitat [14]. According to the difference of reproduction strategy, fish can be grouped into unisexuals, hermaphrodites and gonochorists [15]. The majority of fishes are gonochorism, and hermaphroditic phenomena are also common, which have been reported in some fishes including rice field eel, black sea bream (Acanlhopagrus schegeli) and grouper (Epinephelus coioides) [2,16-18]. Even in gonochoristic rainbow trout (Oncorhynchus mykiss), it was found that the sex steroid level change could induce hermaphrodites, and the hermaphrodites produced YY males by self-fertilization of the generated sperm and egg [19].

1.2 Discovery of multiple modes of unisexual gynogenesis and sexual reproduction and the genetic breeding application in polyploid gibel carp

Since the first unisexual fish, the Amazon molly Poecilia formosa, was found by American ichthyologist Hubbs et al. in 1932, unisexual all-female populations had been reported in about 30 fish species, and these unisexual fishes had been demonstrated to reproduce by gynogenesis, hybridogenesis or parthenogenesis [20-23]. Polyploid gibel carp, Carassius auratus gibelio, because of the existence of a minor but significant portion of males in natural populations and the discovery of multiple modes of unisexual gynogenesis and sexual reproduction in some gynogenetic clones [23], has been noted extensively $[12,24]$. Through a series of studies, various gynogenetic clones and the clone-specific genetic markers have been identified, and used to perform studies on the evolutionary and ecological genetics [25-33]. Moreover, some important functional genes have been screened, and utilized to study the developmental genetics and regulative mechanism on reproduction [34-40]. In addition, a novel nucleo-cytoplasmic hybrid clone $\mathrm{A}+$ has been created by sexual mating between clone $\mathrm{D}$ female and clone A male, and rapidly multiplied up to several hundred millions by subsequent more than five generations of unisexual gynogenesis [41]. Owing to the significant growth superiority and better resistance to myxosporean pathogen parasitized in the liver [41,42], the novel clone variety, as nominated "CAS III", has been cultured throughout China.

\section{Sexual dimorphism and its genetic basis in fish}

\subsection{Diversity of sexual dimorphism in fish}

Sexual dimorphism is commonly defined as the difference between male and female individuals. Sexual dimorphism in fish not only includes size dimorphism, shape dimorphism and color dimorphism, but also comprises sexual differences in physiology and behavior $[43,44]$. Long-term field surveys and aquaculture practices have observed significant size dimorphism between male and female individuals in more than 20 fish species. As listed in Table 1, in more than 10 fish species including common carp (Cyprinus carpio), rainbow trout (Oncorhynchus mykiss), Japanese flounder (Paralichthys olivaceus), and half-smooth tongue sole (Cynoglossus semilaevis), the females mature later than the males so that the nutrient substance in females is able to transform into body composition and body weight during maturation and reach a larger size than males. On the contrary, males mature later and grow faster in more than 10 fish species, such as tilapia (Oreochromis niloticus), yellow catfish (Pelteobagrus fulvidraco), channel catfish (Ictalurus punctatus) and rusty parrotfish (Scarus ferrugineus), in which males are bigger than females. Especially in some sex-changing fishes from females to males, the males grow much faster than females because large males have been believed to monopolize the right to mate with many females [70]. Additionally, sexual dimorphism was also observed in body shape and color in some ornamental fishes. For example, male swordtail fish (Xiphophorus helleri) uniquely has a needle-like fin extended from caudal fin margin, which owns more ornamental value than the female [71]. The skin of male bitterling fish (Rhodeus ocellatus) becomes colorful during its breeding season, while the female bitterling fish is just silver white in the body [72]. Recent studies have indicated that the physiological responses of the nervous system and sense organs also have significant difference between males and females in some fish species, and lead to sexual dimorphism in behavior [73].

\subsection{Genetic basis of sexual dimorphism in fish}

Sexual dimorphism commonly exists throughout the animal 
Table 1 The known fish species with sexual dimorphism in size

\begin{tabular}{|c|c|c|c|}
\hline Size dimorphism & Species & Sex chromosome system & References \\
\hline \multirow{10}{*}{ Bigger in males } & Yellow catfish (Pelteobagrus fulvidraco) & $\mathrm{XX}-\mathrm{XY}$ & {$[45]$} \\
\hline & Nile tilapia (Oreochromis niloticus) & $\mathrm{XX}-\mathrm{XY}$ & [46] \\
\hline & Blue tilapia (Oreochromis aureus) & ZW-ZZ & {$[47]$} \\
\hline & Ussuri catfish (Pseudobagrus ussuriensis) & $X X-X Y$ & [48] \\
\hline & Channel catfish (Ictalurus punctatus) & $\mathrm{XX}-\mathrm{XY}$ & [49] \\
\hline & Snakehead (Channa argus Cantor) & $\mathrm{XX}-\mathrm{XY}$ & {$[50]$} \\
\hline & Blackfin sandperch (Parapercis snyderi) & $?$ & {$[52]$} \\
\hline & Bluefin tuna (Thunnus maccoyii) & $?$ & [53] \\
\hline & Dark sleeper (Odontobutis obscura) & $?$ & {$[54]$} \\
\hline & Rusty parrotfish (Scarus ferrugineus) & $?$ & {$[55]$} \\
\hline \multirow{13}{*}{ Bigger in females } & Common carp (Cyprinus carpio) & $\mathrm{XX}-\mathrm{XY}$ & [56] \\
\hline & Bastard halibut (Paralichthys olivaceus) & $X X-X Y$ & {$[57]$} \\
\hline & Southern Flounder (Paralichthys lethostigma) & $\mathrm{XX}-\mathrm{XY}$ & [58] \\
\hline & Atlantic salmon (Salmo salar) & $X X-X Y$ & {$[60]$} \\
\hline & Sea bass (Dicentrarchus labrax) & $X X-X Y$ & {$[61]$} \\
\hline & Yellow perch (Perca flavescens) & $\mathrm{XX}-\mathrm{XY}$ & {$[62]$} \\
\hline & Atlantic halibut (Hippoglossus hippoglossus) & $\mathrm{XX}-\mathrm{XY}$ & [63] \\
\hline & Chinook salmon (Oncorhynchus tshawytscha) & $X X-X Y$ & {$[64]$} \\
\hline & Herring smelt (Oncorhynchus kisutch) & $X X-X Y$ & {$[65]$} \\
\hline & Half-smooth tongue sole (Cynoglossus semilaevis) & ZW-ZZ & {$[66]$} \\
\hline & European eels (Anguilla Anguilla) & $?$ & {$[67]$} \\
\hline & Spotted scat (Scatophagus argus) & $?$ & {$[68]$} \\
\hline & Silver barb (Puntius gonionotus) & $?$ & [69] \\
\hline
\end{tabular}

kingdom, but our knowledge for its mechanism is very limited. A large number of studies have shown that sexual dimorphism in vertebrates mainly results from genetic selection during the evolutionary process [74], and is the consequence of differential expression of sex-biased genes in development and growth of embryo, larval and adult [75,76]. Theoretically, sex chromosomes and the genes located on them may play critical roles in sexual dimorphism $[77,78]$. In some cases, however, sex chromosomes are not the leader of sexual dimorphism, because quantitative genetic studies have observed discordance between sex chromosomes and phenotypic data [79]. Genetic architecture of threespine stickleback fish (Gasterosteus aculeatus) is very similar between males and females, but many traits show significant sexual difference, suggesting that genetic constraints for evolution of sex dimorphism might not be so severe and absolute as generally thought [80].

A great deal of data accumulation of the completely sequenced genomes, transcriptomes, and proteomics from model and farmed fishes provides a previous basis for us to explore the genetic and molecular mechanism of sex dimorphism [12]. As we have known, size dimorphism in vertebrates mainly results from the different growth rate between male and female individuals, and the growth rate is regulated by growth hormone $(\mathrm{GH}) /$ insulin-like growth factor (IGF) and other related factors secreted by the hypothalamic-pituitary-gonad axis and other tissues [81]. So far, the discovered factors in fish growth hormone axis include GH/growth hormone receptor (GHR)/IGFs [82] and corticotropinreleasing hormone (CRH)/pro-opiomelanocortin (POMC)/melanocortin receptors (MCRs) [83]. In swordtails of the genus Xiphophorus, the expression level of $m c 4 r$ gene was found to accordingly increase in XX females or males, small XY males, intermediate and large XY males. In addition, its B allele lacking two cysteine residues is only expressed in XY males, and its expression level is closely related to male body size [84]. In Nile tilapia, comparative transcriptome analysis in ovary and testis also revealed differential expression genes during sex differentiation [85]. Recently, Jing et al. [86] used solexa high-throughput sequencing technology to compare gene and microRNA expression patterns in gonads of $\mathrm{XX}$ females, $\mathrm{XY}$ males and YY super-males, and attempted to reveal the molecular basis of sexual dimorphism in body size through analyzing expression difference of growth-related genes between adult males and females in the hypothalamus and pituitary (unpublished data).

In addition, it has been found in some fishes that sexual dimorphism in color, body shape, physiology and behavior is also controlled by some key genes. For example, in Lake Malawi cichlid fishes, the color dimorphism between males and females is probably controlled by the expressional and functional difference of pax7 gene [87], and the neo-sex chromosome in stickleback has significant correlation with the physiology and reproductive behavior [88]. 


\section{Genetic basis of sex determination in fish}

\subsection{Diversity of sex determination systems in fish}

In teleost fish, sex determination is a plastic process that is usually governed by the interaction between genetic (genetic sex determination) and environmental (environmental sex determination) factors $[89,90]$. A variety of environmental factors, such as hormones, temperature, $\mathrm{pH}$, density, light intensity and hypoxia, may affect sex determination pathway. Much evidence indicates that in many fish species with genetic sex determination, environmental factors such as temperature may overwhelm the effect of genetic factors at the edge of temperature tolerance threshold [91,92].

For most gonochoristic fish species, the mechanism of genetic sex determination is usually determined by either a critical gene or polygene on sex chromosomes or autosomes [8]. In single gene system, sex is determined by a critical gene on sex chromosome [6]. XX/XY male heterogametic system and ZZ/ZW female heterogametic system are two main sex determination systems in fish species, and several variants including $\mathrm{XX} / \mathrm{XO}, \mathrm{XX} / \mathrm{XY} 1 \mathrm{Y} 2, \mathrm{X} 1 \mathrm{X} 2 \mathrm{X} 1 \mathrm{X} 2 /$ $\mathrm{X} 1 \mathrm{X} 2 \mathrm{Y}, \mathrm{X} 1 \mathrm{X} 2 \mathrm{X} 1 \mathrm{X} 2 / \mathrm{X} 1 \mathrm{X} 2 \mathrm{X} 1, \mathrm{ZZ} / \mathrm{ZO}$ and $\mathrm{ZZ/ZW} 1 \mathrm{~W} 2$ also exist in a few of fish species, whereas no heteromorphic sex chromosomes have been found in most of fish species [93]. Even in fish with heteromorphic sex chromosomes, it is difficult to identify sex chromosomes by cytogenetics and fluorescence in situ hybridization techniques, since the differentiation and divergent degree of sex chromosome is still very low [4,94].

Many current data from most studies have shown that sex of some fish species is determined by either several loci dispersed throughout the genome, or multiple allele combinations located on a preferential pair of chromosomes, which has been designated as polygenic sex determination (PSD) system [95,96]. In zebrafish [97,98], Lake Malawi cichlid fish [99] and European sea bass [100] that do not have typical $\mathrm{XX} / \mathrm{XY}$ or ZZ/ZW sex determination system, sex is determined by multiple genes on several chromosomes. At whiles, sex determination locus is variable in different strains or subspecies of the same fish species, in which there are more than two types of sex determination systems. These situations may be caused by several reasons including recombination or fusions between the extant sex chromosomes and autosomes [101-103].

\subsection{Plasticity of sex differentiation in fish}

In most gonochoristic fish, such as yellow catfish, meda$\mathrm{ka}$ (Oryzias latipes) and common carp, the gonad development process initiates from undifferentiated state, and then differentiates into testis or ovary. However, in a small number of gonochoristic fish including zebrafish and European eel, the undifferentiated gonad first develops into ovary-like structure. At juvenile stage, the ovarian structure is regressed in near half of the population and eventually develops into a normal testis $[104,105]$. Sex differentiation is dependent on sex determination, but the whole process of embryonic development, sex determination and differentiation is exposed to the outside environment with many variable factors, so that fish must utilize diverse types of sex determination mechanisms and plastic patterns of sex differentiation to gradually adapt to the habitat environment during the evolution $[6,92,106]$.

In most of fish species, no matter whether there is a sex determining gene or not, the change of sex steroid concentration or temperature is able to induce sex reversal, and thereby leads to the discordance between genetic and physiological phenotypes $[44,92,93]$. Temperature is the main factor affecting sex differentiation, because a lot of observations have shown in most of temperature-sensitive fishes that the male proportion increases along with elevation of hatching temperature, and low temperature is able to induce ovarian development [107-109]. Estrogen and androgen are essential for female and male sexual differentiation and gonadal development. At early stage of fish sex differentiation, when endogenous steroids are not produced or not enough in vivo, optimal dose of exogenous steroids can change the direction of gonadal sex differentiation [6,92]. In protogynous hermaphrodite groupers, $17 \alpha$-methyltestosterone could induce sex reversal from females to males [110], which lead to up-regulation of dmrtl expression [111,112], and down-regulation of cyp19ala and sox3 expression $[113,114]$. On the other hand, estrogen treatment could promote male-to-female sex reversal in tilapia, and resulted in the inhibition of dmrtl expression [115]. When $\mathrm{XX}$ medaka was exposed to high water temperature, the physiological males could be induced along with decreasing expression of cypl9ala, whereas co-treatment with 17 $\beta$-estradiol (E2) inhibited the sex reversal [116]. Besides sex hormone, aromatase inhibitors (Fadrozole and Letrozole) could reduce the enzyme activity and thereby led to masculinization, which had been used to induce female-to-male sex reversal in tilapia and medaka $[117,118]$. Godwin analyzed the influence of social factors on sex determination and differentiation of reef fish, and explored the advantages of this plasticity mechanism in evolution [119]. In a sex-changing fish Thalassoma bifasciatum, it was found that whether the males either directly differentiated or firstly produced as females and then sex-reversed to males largely depended on the social environment signals that they received at early stage of sex determination [120].

\subsection{Sex-determining (SD) genes in fish}

\subsubsection{SD genes in fish with $X X / X Y$ sex determination system}

$\mathrm{SD}$ genes mainly refer to the genes that transiently express in the undifferentiated gonad and directly determine the 
bipotential gonad into either a testis or an ovary. Sry gene, the first SD gene discovered in vertebrates, is located on Y-chromosome and initiates testicular differentiation [121,122]. Dmy/dmrtlbY is the first SD gene identified in fish, and it is also located on Y-chromosome in Oryzias latipes, a species of medaka [123]. Subsequently, five other SD-related genes, such as gsdf in Oryzias luzonensis, sox3 in Oryzias dancena, amhr2 in Takifugu rubripes, Amhy in Odontesthes hatchery and $s d Y$ in Oncorhynchus mykiss, were respectively identified from several teleost fish with $\mathrm{XX} / \mathrm{XY}$ sex determination system. During testis differentiation, their expressed products were also localized on early differentiating cells of testis tissue. Moreover, the mutation of $d m y, s o x 3, a m h r 2$ and $s d Y$ or knockdown of amhy led to male-to-female sex reversal in XY males, while transgenic over-expression of sox3, $s d Y$ and $g s d f$ genes caused female-to-male sex reversal in XX females, suggesting that they should be male SD genes and play critical roles in male sex determination [124-128]. A large number of studies have confirmed that most male SD genes including $d m y$ in medaka, are the duplications of Dmrtl ( $d s x$ and mab-3 related transcription factor 1) $[129,130]$. It had been detected in medaka that dmrt1 mutation caused a male-to-female sex reversal, suggesting that dmrtl should be essential for maintaining testis differentiation in the Dmy-triggered male sex determination pathway $[131,132]$.

Actually, dmy has not been revealed as a universal SD gene in any other kind of fish, soon after it was identified as the first SD gene in medaka Oryzias latipes, suggesting that SD genes are diverse in fish. In other medaka fish Oryzias luzonensis and Oryzias dancena, gsdf and sox3 take the place of $d m y$ as new SD genes [124,125]. Using genome-wide linkage analysis and association mapping strategy, Kamiya et al. [126] have found that only a SNP (C/G) polymorphism in the kinase domain of Amhr2 gene is associated with sex phenotype in fugu and two other species of Takifugu, but not in Tetraodon. These data suggest that sex determination is diverse among different species even in the same genus. In addition, the hotei homogenous mutation in the kinase domain of Amhr2 also led to male-to-female sex reversal in XY medaka males [133]. Therefore, Amhr2 plays a pivotal role in sex determination of fugu and meda$\mathrm{ka}$, mainly through the function of its kinase domain.

\subsubsection{Sex-determining genes in fish with $Z Z / Z W$ sex de- termination system}

Sex determination system in birds is $\mathrm{ZZ}$ (male)/ZW (female) system, and the first male SD gene, Dmrtl on the Z-chromosome, is identified in chickens [134]. DM-W, a W-linked paralogue of Dmrtl that antagonizes the transcriptional activity of DMRT1, was further identified as an ovary-determining gene from frog Xenopus laevis with a ZZ/ZW SD system [135,136]. In teleost fish with ZZ/ZW sex determination system, no definitive SD genes have been detected, but many candidate SD genes have already ap- peared.

Recently, Chen et al. [137] reported the whole genome sequencing of a $\mathrm{ZZ/ZW}$ type fish, the half-smooth tongue sole. Through phylogenetic analysis, a high level of homology was detected between half-smooth tongue sole and avian $\mathrm{W}$ and $\mathrm{Z}$ chromosomes. They found a functional dmrtl located on the Z-chromosome and its homologous pseudogene on the W chromosome. Similar to the expression pattern of other SD genes, the dmrtl was revealed to specifically express in male germ cells and pre-somatic cells of the undifferentiated gonad at sex-determination stage and persists at high levels during testis development. In $\mathrm{ZW}$ females, the dmrtl promoter was hypermethylated and silenced, whereas it was demethylated and activated in $\mathrm{ZW}$ pseudomales, which resulted in the upregulation of $d m r t 1$ expression to a level as normally developing $\mathrm{ZZ}$ males by dosage compensation. Moreover, female-specific genes on $\mathrm{W}$ chromosome were found to be inhibited by methylation regulation in pseudomales [138,139]. All the above data suggest that, similar to avian, not only part of the genes on fish $\mathrm{Z}$ chromosome has effective and variable dosage compensation, but also $\mathrm{W}$ chromosome contains a part of sex determination or the dosage compensation mechanism [139]. Obviously, the novel understanding from whole genome sequence analysis of the farmed fish is an exciting stimulus for further study on SD genes of ZZ/ZW system [140,141].

In addition, two potential SD genes, amh and dmrta2, were mapped to the sex-determination loci in ZZ/ZW type turbot (Scophthalmus maximus) and tilapia by applying sex-associated markers and QTL analysis [142,143]. Xu et al. [144] also observed regulative role of dmrta2 in zebrafish spermatogenesis.

\subsection{Network modules of sex determination in fish}

The known SD genes in fish, such as $d m y$ and amhy, have been demonstrated to be respective duplicated gene of the autosomal dmrtl and amh on Y chromosome [123,127]. Gene duplication is a common phenomenon because all teleosts are hypothesized to have experienced another "fish-specific" (3R) whole genome duplication event during the ancestral lineage evolution [32,145-147]. Actually, the master SD genes in vertebrates, such as Sry, dmy, amhr2, amhy and $g s d f$ are either key factors for gonadal differentiation or their duplications. However, $s d Y$, a male-specific gene on $\mathrm{Y}$ chromosome in rainbow trout and most species of salmonids, is a truncated copy of autosomal irf9 (interferon regulatory factor 9) [148]. Recent continuous discovery about new SD genes strengthens the hypothesis that not only downstream key factors or related genes for gonadal differentiation but also some other genes involved in different developmental process are able to recruit to the top signal of SD pathway through either directness or duplication $[15,149]$.

Undifferentiated gonad in fish is commonly thought to 
have double potentials to trigger testis development or ovary development. When sex determination "switch" is initiated by master sex-determining gene, a genetic network of sex determination and differentiation that is composed by some conserved sex differentiation genes will be activated (Figure 1). These downstream sex-related genes can regulate the expression of sex steroid hormones, and thereby direct the development of functional gonads with the sex phenotype [150-152]. A new idea believes that fish sex determination is neither a single genetic cascade reaction nor a result of hierarchical cascades by genetic network, but the reciprocal links between different genetic modules which functionally interact with each other [15,153]. As shown in Figure 1, in fish with $\mathrm{XX} / \mathrm{XY}$ sex determination system, high expression of the master male sex determination gene on $\mathrm{Y}$ chromosome, such as dmy, sox3, amhr2, sdY, or amhy, is able to initiate different modules in genetic network of sex determination and testis differentiation so that activate the essential genes for testis development, such as $d m r t 1$, sox 9 and $a m h$, and thereby completes male formation. Conversely, the absence of master male sex determination gene on $\mathrm{X}$ chromosomes leads to other module activation in genetic network of female sex determination and ovary differentiation, and thereby induces the expression of ovary formation-related genes, such as cyp19al, foxl2, sfl and wnt4 [154,155].

Recent findings in sex-changing fish indicate that some sex differentiation-related genes are also regulated by epigenetic modifications $[156,157]$. In juvenile males of European sea bass, the cyp19a promoter was found to have double levels of DNA methylation than the females, in which exposure to high temperature increased the promoter methylation levels in females and suppressed the ability of SF-1 and Foxl2 to stimulate its transcription [156]. Similarly, in hermaphrodite and sex-changing rice field eel, the cyp19ala promoter was also discovered to be hypermethylated in the ovotestis and testis compared with the ovary, and the natural

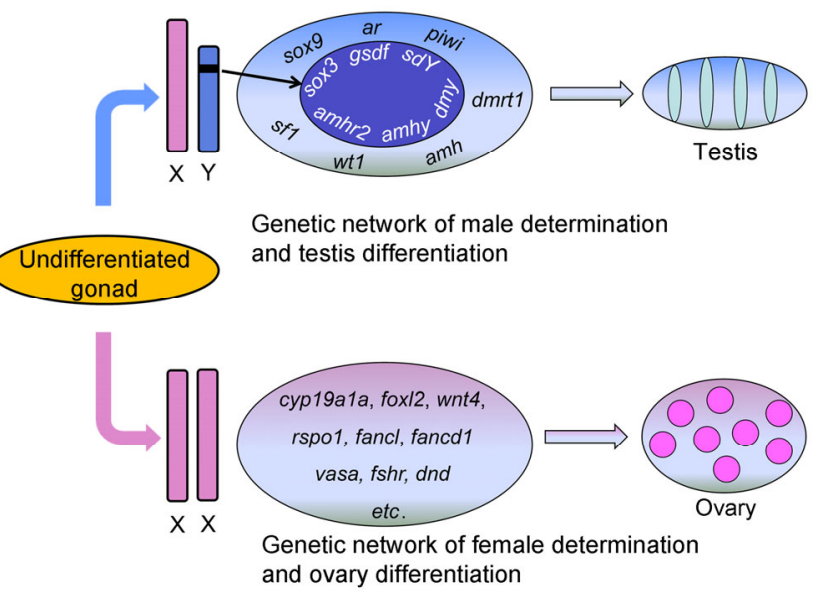

Figure 1 A schematic diagram of sex determination and gonad (testis or ovary) differentiation in fish with XX/XY sex determination system. sex changing could be reversed by DNA methylation inhibitor 5-aza-2'-deoxycytidine [157].

\section{Sex control biotechnology and its breeding application in fish}

Growth is one of the most valuable economic traits for fish genetic improvement. Because some fish species display different growth rate and body size, all-female or all-male population production has significant economic implications in aquaculture. As mentioned above, fish genetic breeding scientists have performed a lot of studies in some aquaculture fish species with growth and size dimorphism between females and males. Through these studies, sex-linked genetic markers or X chromosome-linked and Y chromosome-linked genetic markers and the markerassisted sex control breeding biotechnology have been successfully exploited, and thereby provided convenient and practical technological approaches for sex control breeding application in fish $[12,158,159]$. In the past five years, only Chinese scientists have successfully produced many mono-sex novel varieties in some farmed fish species, such as Yellow catfish "all-male No.1", all-female "North flounder No.1", all-female "North flounder No.2" and Tilapia "Luxiong No.1". Based on these significant breakthrough advances, this section will highlight some novel ideas and new biotechnological approaches for future sex control breeding in fish.

\subsection{Interspecific hybridization and production of all-males and all-females in fish}

Interspecific hybridization not only improves fish economic traits including growth rate, survival rate, disease resistance, cold tolerance and hypoxia tolerance $[160,161]$, but also utilizes to produce high ratio offspring of males or females. The most representative case is massive production of all-male population by interspecific hybridization between different tilapia species. As early as 1960, Hickling [162] firstly reported the generation of all-male tilapia population by crossing female $O$. mossambicus (XX) with male $O$. hornorum (ZZ). Subsequently, a large number of interspecific crossings were performed between multiple tilapia species, and the hybrid offspring between Nile tilapia and Aureus tilapia was found to have significant advantages in growth, survival and male proportion [163,164]. Moreover, when Nile tilapia was hybridized with the variety "Xiaao No.1" selected from blue tilapia by population breeding, the hybrid offspring produced more than $93 \%$ males that were applied to massive aquaculture in China [165]. In bass, $100 \%$ all-female offspring could be generated by specific hybridization between different species [166], but the sex determination system and mechanism for monosex generation remain unclear [167]. 


\subsection{Artificial gynogenesis and all-female population production}

As another important approach for producing monosex fish population, artificial gynogenesis generally refers to the haploid egg activation by genetically inactivated sperm and the activated egg development into diploid offspring after chromosome doubling. Therefore, the genetic information of these offspring is almost from their female parent [4]. After artificial gynogenesis, a XX all-female population will be produced if the parents have a XY/XX sex determination system, whereas ZZ male and WW female, not all-female offspring will be theoretically produced from the parents with ZZ/ZW sex determination system.

Gibel carp has the capacity of unisexual gynogenesis, and it is feasible to produce all-female offspring when its eggs are activated by heterologous common carp sperm, in which the aquaculture of all-female gynogenetic offspring has become a typical case of sex control breeding application in fish aquaculture [23]. Through a combining approach of artificial gynogenesis and sex reversal, all-female population was also produced in common carp and used for aquaculture practice [60]. Recently, artificial gynogenesis has been performed in many marine fish species, such as flounder [168], red sea bream (Pagrosomus major) [169], sea bass [170], spotted halibut (Verasper variegatus) [171], and half-smooth tongue soles [172]. Especially in flounder, several gynogenetic clones have been obtained [173-175]. Based on these artificial clone strains, the Beidaihe experiment station of the Chinese Academy of Fishery Sciences have successively bred two aquaculture varieties of flounder, "north flounder No.1" and "north flounder No.2".

Generally, the gynogenetic offspring is composed of all-females. However, a certain part of male individuals have also been recorded in some gynogenetic fishes resulting from distant hybridization, such as in Poecilia formosa and in Carassius auratus red var. [176-178], which may have exploitable significance and potential in fish genetic breeding.

\subsection{Identification of sex-specific markers and sex chromosome-specific markers}

For most fish species, the degree of sex chromosome differentiation is very low and it is difficult to discriminate through sex chromosome morphology. In addition, fish sex is easily influenced by environment factors, especially by temperature [179], which often results in inconstancy between physiology phenotype and sex genotype. So it is important and meaningful to search for a convenient and forthright method to identify fish genetic sex in aquaculture. In some fish species, fish genetic scientists have successfully identified a great number of sex-specific or sex chromosome-specific markers by multiple techniques including AFLP (amplified fragment length polymorphism), SNP (single nucleotide polymorphism), RAPD (random amplified polymorphic DNA), SSR (simple sequence repeats) and QTL (quantitative trait locus) (Table 2). Obviously, these markers establish a profound foundation for identifying fish genetic sex and sex chromosomes, and offer a high efficient technology approach for massive production of all-male or all-female populations $[12,180]$.

\subsection{Biotechnological approaches of sex control breed- ing in fish}

During early gonadal differentiation, exogenous steroid hormone treatment could effectively induce sex reversal in fish. So far, the hormone-induced sex reversal has been prohibited to directly produce monosexual fish population, because we are still uncertain whether the hormone derivatives generated during the metabolic process can quickly degenerate or not $[4,12,197]$. In consideration of food security, the feasible way is to use the hormone-induced sex reversal fish as parents to breed monosexual offspring in aquaculture.

In common carp and crucian carp, Chinese scientists have successfully incorporated artificial gynogenesis and sex reversal techniques to quickly establish all-female populations $[198,199]$. Based on the identification of $X$ chromosome-specific and $\mathrm{Y}$ chromosome-specific markers $[49,180]$, Yellow catfish "all-male No. 1", a novel aquatic variety, has been produced by using a biotechnological approach of sex control breeding [12,200]. Accordingly, we have proposed an integrative sex control breeding approach for mass production of all-male population in $\mathrm{XX} / \mathrm{XY}$ sex determination system fish by 17 $\alpha$-ethinyloestradiol (EE2) treatment and by $\mathrm{Y}$ chromosome-specific marker (YSM) and X chromosome-specific marker (XSM) selection [12]. The technological approach for production of all-female population is simpler than that for all-male population in $\mathrm{XX} / \mathrm{XY}$ fish. The XX physiological males can be either produced by sex reversal after artificial gynogenesis, or selected by the Y chromosome-specific marker (YSM) and $\mathrm{X}$ chromosome-specific marker (XSM) from sex reversal progeny through $17 \alpha$-methyltestosterone (MT) treatment. And, the batch XX physiological males can be obtained from the MT treated offspring between XX male and XX female mating. Finally, mass production of all-females can be produced by the mating of XX males and females (Figure 2).

\section{Conclusion and outlook}

Over the past few decades, the slow progress in discovery of SD genes and sex chromosome in fish mainly results from the shortness of genetic information and genomic resources. Recently, rapid development of high-throughput DNA sequencing technique, massive accumulation of ge- 
Table 2 A list of sex-specific markers or sex chromosome-specific markers and their associated genes

\begin{tabular}{|c|c|c|c|c|c|}
\hline Species & $\begin{array}{l}\text { Sex determination } \\
\text { system }\end{array}$ & $\begin{array}{l}\text { The identified } \\
\text { tech niques }\end{array}$ & Marker type and quantity & $\begin{array}{l}\text { Associated } \\
\text { genes }\end{array}$ & References \\
\hline \multirow[t]{2}{*}{ Yellow catfish (Pelteobagrus fulvidraco) } & $\mathrm{XX} / \mathrm{XY}$ & AFLP & Two X- and Y-specific markers & & [49] \\
\hline & & genomic walking & $\begin{array}{l}\text { Two } X \text { - and } Y \text {-specific markers; } \\
\text { One different length } X \text { and } Y \text { markers }\end{array}$ & & [180] \\
\hline Channel catfish (Ictalurus punctatus) & $\mathrm{XX} / \mathrm{XY}$ & $\begin{array}{l}\text { Sequencing and } \\
\text { analysis }\end{array}$ & One male-specific marker & & [181] \\
\hline African catfish (Clarias gariepinus) & $\mathrm{XX} / \mathrm{XY}$ & RAPD & Two male-specific markers & & [182] \\
\hline \multirow[t]{2}{*}{ Rainbow trout (Oncorhynchus mykiss) } & $\mathrm{XX} / \mathrm{XY}$ & AFLP & Fifteen male-specific markers & & [183] \\
\hline & & gene expression & One Y-linked marker & $s d Y$ & [128] \\
\hline \multirow[t]{2}{*}{ Patagonian pejerrey (Odontesthes hatcheri) } & $\mathrm{XX} / \mathrm{XY}$ & AFLP & One male-specific marker & & [184] \\
\hline & & gene expression & One Y-linked marker & amhy & [127] \\
\hline Japanese pufferfish (Takifugu rubripes) & $\mathrm{XX} / \mathrm{XY}$ & SNP & One Y-linked marker & Amhr2 & [126] \\
\hline Japanese medaka (Oryzias latipes) & $\mathrm{XX} / \mathrm{XY}$ & gene expression & One Y-linked marker & dmy & [123] \\
\hline Philippine medaka (Oryzias luzonensis) & $\mathrm{XX} / \mathrm{XY}$ & gene expression & One Y-linked marker & gsdf & [124] \\
\hline Indian ricefish (Oryzias dancena) & $\mathrm{XX} / \mathrm{XY}$ & gene expression & One Y-linked marker & $\operatorname{sox} 3$ & [125] \\
\hline Platyfish (Xiphophorus maculates) & $\mathrm{XX} / \mathrm{XY}$ & Sequence analysis & One Y-linked marker & $M C 4 R$ & [84] \\
\hline Fathead minnow (Pimephales promelas) & $\mathrm{XX} / \mathrm{XY}$ & AFLP & $\begin{array}{l}\text { Eight male-specific markers } \\
\text { One male-specific marker }\end{array}$ & & [185] \\
\hline \multicolumn{2}{|c|}{ Nine-spined stickleback (Pungitius pungitius)XX/XY } & SSR & One male-specific marker & & [186] \\
\hline Common carp (Cyprinus carpio) & $\mathrm{XX} / \mathrm{XY}$ & RAPD & One male-specific marker & & [187] \\
\hline Nile tilapia (Oreochromis niloticus) & $\mathrm{XX} / \mathrm{XY}$ & $\begin{array}{l}\text { AFLP } \\
\text { RAPD, AFLP }\end{array}$ & $\begin{array}{l}\text { Three male-specific markers } \\
\text { Four X- linked markers } \\
\text { Five Y-linked markers }\end{array}$ & & {$[188]$} \\
\hline \multirow[t]{2}{*}{ Turbot (Scophthalmus maximus) } & ZZ/ZW & RAPD & One female-specific marker & wnt 4, foxl 2 & [190] \\
\hline & & RAPD & One male-specific marker & amh, dmrta2 & [191] \\
\hline Spotted halibut (Verasper variegatus) & $\mathrm{ZZ/ZW}$ & AFLP & Two female-specific markers & & [192] \\
\hline Atlantic halibut (Hippoglossus stenolepis) & $\mathrm{XX} / \mathrm{XY}$ & SSR & Three female-specific markers & & [193] \\
\hline Half-smooth tongue sole & ZZ/ZW & AFLP, SSR & Seven and one female-specific markers & & {$[70,174]$} \\
\hline (Cynoglossus semilaevis) & & Genomic sequencing & One Z-linked marker & $d m r t 1$ & [137] \\
\hline Yellowtail (Seriola quinqueradiata) & ZZ/ZW & SSR & One female-specific marker & & [194] \\
\hline Rock bream (Oplegnathus fasciatus) & $\mathrm{X}_{1} \mathrm{X}_{1} \mathrm{X}_{2} \mathrm{X}_{2} / \mathrm{X}_{1} \mathrm{X}_{2} \mathrm{Y}$ & AFLP & Four male-specific markers & & [195] \\
\hline matrinxã ( Brycon amazonicus ) & & RAPD & One female-specific marker & $P I G W$ & [196] \\
\hline
\end{tabular}

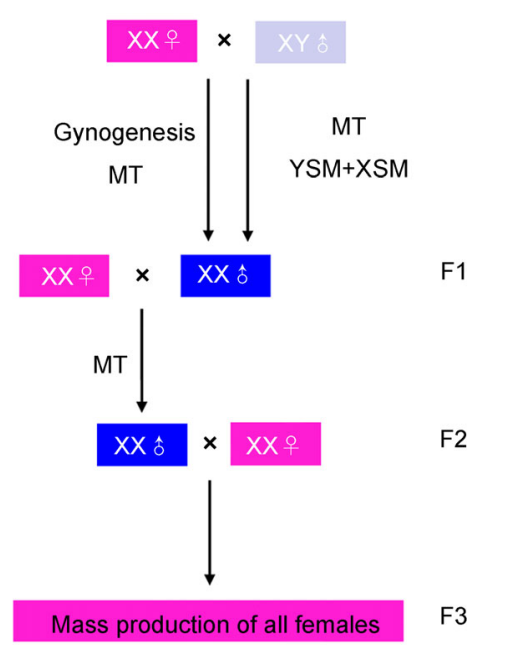

Figure 2 A schematic diagram of mass production of all-female population through an integration approach of gynogenesis, methyltestosterone (MT) treatment, and X chromosome-specific marker (XSM) and Y chromosome-specific marker (YSM) identification in fish with $\mathrm{XX} / \mathrm{XY}$ sex determination system.

nomic and transcriptomic data, and extensive utilization of comparative phylogenetic methods have greatly promoted the pace of genetic basis studies on fish sex determination [201]. Many sex-linked or sex chromosome-specific molecular markers have been rapidly developed and start to be efficiently applied to aquaculture. Moreover, the gene targeting and editing approaches, such as TALEN (transcription activator-like effector nuclease) and CRISPR (clustered regularly interspaced short palindromic repeats)/Cas9 (CRISPR-associated 9), have made it easier to perform functional experiments in fish [202-204]. It is expected that a new era is coming for studying genetic basis of sex dimorphism and sex determination and biotechnological manipulation of sex control breeding.

This work was supported by the National Key Basic Research Program (2010CB126301), the Special Fund for Agro-scientific Research in the Public Interest from Ministry of Agriculture of China (2009030406), the Autonomous Project of State Key Laboratory of Freshwater Ecology and Biotechnology (2011FBZ17), and the National Natural Science Foundation of China (31301931).

1 Bell G. The Masterpiece of Nature: the Evolution and Genetics of Sexuality. Berkeley: The University of California Press, 1982

2 Liu CK. Rudimentary hermaphroditism in the symbranchoid eel, Monopterus javanensis. Sinensia, 1944, 15: 1-8 
3 Bullough WS. Hermaphroditism in the lower vertebrates. Nature, 1947, 160: 9-11

4 Gui JF. Genetic Basis and Artificial Control of Sexuality and Reproduction in Fish (in Chinese). Beijing: Science Press, 2007

5 Long JA. The Rise of Fishes: 500 Million Years of Evolution. 2nd ed. Baltimore: The Johns Hopkins University Press, 2010

6 Devlin RH, Nagahama Y. Sex determination and sex differentiation in fish: an overview of genetic, physiological, and environmental influences. Aquaculture, 2002, 208: 191-364

7 Kobayashi Y, Nagahama Y, Nakamura M. Diversity and plasticity of sex determination and differentiation in fishes. Sex Dev, 2013, 7: $115-125$

8 Kikuchi K, Hamaguchi S. Novel sex-determining genes in fish and sex chromosome evolution. Dev Dyn, 2013, 242: 339-353

9 Food and Agriculture Organization of the United Nations. The State of World Fisheries and Aquaculture 2014. Rome, 2014. ISBN 978-92-5-108275-1

10 Naylor RL, Goldburg RJ, Primavera JH, Kautsky N, Beveridge MC, Clay J, Folke C, Lubchenco J, Mooney H, Troell M. Effect of aquaculture on world fish supplies. Nature, 2000, 405: 1017-1024

11 James HT, Geoff LA. Fish as food: Aquaculture's contribution. EMBO Rep, 2001, 21: 958-963

12 Gui JF, Zhu ZY. Molecular basis and genetic improvement of economically important traits in aquaculture animals. Chin Sci Bull, 2012, 57: 1751-1760

13 Chen J, Hu W, Zhu ZY. Progress in studies of fish reproductive development regulation. Chin Sci Bull, 2013, 58: 7-16

14 Jalabert B. Particularities of reproduction and oogenesis in teleost fish compared mammals. Reprod Nutr Dev, 2005, 45: 261-279

15 Heule C, Salzburger W, Bohne A. Genetics of sexual development: an evolutionary playground for fish. Genetics, 2014, 196: 579-591

16 Wu GC, Tomy S, Lee MF, Lee YH, Yueh WS, Lin CJ, Lau EL, Chang CF. Sex differentiation and sex change in the protandrous black porgy, Acanthopagrus schlegeli. Gen Comp Endocrinol, 2010, 167: 417-421

17 Liu M, de Mitcheson YS. Gonad development during sexual differentiation in hatchery-produced orange-spotted grouper (Epinephelus coioides) and humpback grouper (Cromileptes altivelis) (Pisces: Serranidae, Epinephelinae). Aquaculture, 2009, 287: 191-202

18 Harikrishnan R, Balasundaram C, Heo M. Fish health aspects in grouper aquaculture. Aquaculture, 2011, 320: 1-21

19 Chevassus B, Devaux A, Chourrout D, Jalabert B. Production of YY rainbow trout males by self-fertilization of induced hermaphrodites. $J$ Hered, 1988, 79: 89-92

20 Schultz RJ. Unisexual fish: laboratory synthesis of a "species". Science, 1973, 179: 180-181

21 Stanley JG. Production of hybrid, androgenetic, and gynogenetic grass carp and carp. Trans Am Fish Soc, 1976, 105: 10-16

22 Neaves WB, Baumann P. Unisexual reproduction among vertebrates. Trends Genet, 2011, 27: 81-88

23 Gui JF, Zhou L. Genetic basis and breeding application of clonal diversity and dual reproduction modes in polyploid Carassius auratus gibelio. Sci China Life Sci, 2010, 53: 409-415

24 Avise JC. Clonality. Oxford: Oxford University Press, 2008

25 Zhou L, Wang Y, Gui JF. Genetic evidence for gonochoristic reproduction in gynogenetic silver crucian carp (Carassius auratus gibelio Bloch) as revealed by RAPD assays. J Mol Evol, 2000, 51: 498-506

26 Yang L, Gui JF. Positive selection on multiple antique allelic lineages of transferrin in the polyploid Carassius auratus. Mol Biol Evol, 2004, 21: 1264-1277

27 Zhu HP, Ma DM, Gui JF. Triploid origin of the gibel carp as revealed by $5 \mathrm{~S}$ rDNA localization and chromosome painting. Chromosome Res, 2006, 14: 767-776

28 Zhu HP, Gui JF. Identification of genome organization in the unusual allotetraploid form of Carassius auratus gibelio. Aquaculture, 2007, 265: 109-117

29 Li FB, Gui JF. Clonal diversity and genealogical relationships of gibel carp in four hatcheries. Anim Genet, 2008, 39: 28-33

30 Jakovlic I, Gui JF. Recent invasion and low level of divergence be- tween diploid and triploid forms of Carassius auratus complex in Croatia. Genetica, 2011, 139: 789-804

31 Jiang FF, Wang ZW, Zhou L, Jiang L, Zhang XJ, Apalikova OV, Brykov VA, Gui JF. High male incidence and evolutionary implications of triploid form in northeast Asia Carassius auratus complex. Mol Phylogenet Evol, 2013, 66: 350-359

32 Li XY, Zhang XJ, Li Z, Hong W, Liu W, Zhang J, Gui JF. Evolutionary history of two divergent Dmrtl genes reveals two rounds of polyploidy origins in gibel carp. Mol Phylogenet Evol, 2014, 78: 96-104

33 Li XY, Li Z, Zhang XJ, Zhou L, Gui JF. Expression characterization of testicular DMRT1 in both Sertoli cells and spermatogenic cells of polyploid gibel carp. Gene, 2014, 548: 119-125

34 Xie J, Wen JJ, Chen B, Gui JF. Differential gene expression in fully grown oocytes between gynogenetic and gonochoristic crucian carps. Gene, 2001, 271: 109-116

35 Dong CH, Yang ST, Yang ZA, Zhang L, Gui JF. A C-type lectin associated and translocated with cortical granules during oocyte maturation and egg fertilization in fish. Dev Biol, 2004, 265: 341-354

36 Peng JX, Xie JL, Zhou L, Hong YH, Gui JF. Evolutionary conservation of Dazl genomic organization and its continuous and dynamic distribution throughout germline development in gynogenetic gibel carp. J Exp Zool Mol Dev Evol, 2009, 312: 855-871

37 Wu N, Yue HM, Chen B, Gui JF. Histone H2A has a novel variant in fish oocytes. Biol Reprod, 2009, 81: 275-283

38 Sun M, Li Z, Gui JF. Dynamic distribution of spindlin in nucleoli, nucleoplasm and spindle from primary oocytes to mature eggs and its critical function for oocyte-to-embryo transition in gibel carp. J Exp Zool A Ecol Genet Physiol, 2010, 313: 461-473

39 Yue HM, Li Z, Wu N, Liu Z, Wang Y, Gui JF. Oocyte-specific H2A variant $\mathrm{H} 2 \mathrm{af} 1 \mathrm{o}$ is required for cell synchrony before mid-blastula transition in early zebrafish embryos. Biol Reprod, 2013, 89: 82

40 Mei J, Yue HM, Li Z, Chen B, Zhong JX, Dan C, Zhou L, Gui JFl. C1q-like factor, a target of miR-430, regulates primordial germ cell development in early embryos of Carassius auratus. Int J Biol Sci, 2013, 10: 15-24

41 Wang ZW, Zhu HP, Wang D, Jiang FF, Guo W, Zhou L, Gui JF. A novel nucleo-cytoplasmic hybrid clone formed via androgenesis in polyploid gibel carp. BMC Res Notes, 2011, 4: 82

42 Zhai YH, Zhou L, Wang Y, Wang ZW, Li Z, Zhang XJ, Gui JF. Proliferation and resistance difference of a liver-parasitized myxosporean in two different gynogenetic clones of gibel carp. Parasitol Res, 2014, 113: 1331-1341

43 Leinonen T, Cano JM, Merilä J. Genetic basis of sexual dimorphism in the threespine stickleback Gasterosteus aculeatus. Heredity (Edinb), 2011, 106: 218-227

44 Dean R, Mank JE. The role of sex chromosomes in sexual dimorphism: discordance between molecular and phenotypic data. J Evol Biol, 2014, 27: 1443-1453

45 Wang D, Mao HL, Chen HX, Liu HQ, Gui JF. Isolation of Y- and $\mathrm{X}$-linked SCAR markers in yellow catfish and application in the production of all-male populations. Anim Genet, 2009, 40: 978-981

46 Beardmore JA, Mair GC, Lewis RI. Monosex male production in finfish as exemplified by tilapia: applications, problems, and prospects. Aquaculture, 2001, 197: 283-301

47 Melard C. Production of a high percentage of male offspring with $17 \alpha$-ethynylestradiol sex-reversed Oreochromis aureus. I. Estrogen sex-reversal and production of F2 pseudofemales. Aquaculture, 1995, 130: $25-34$

48 Jia YH, Huang HZ, Li QQ, Zhang QY. Growth and seasonal changes of sex steroids level and gonad development in female and male Pseudobagrus ussuriensis (in Chinese). Marine Sci, 2012, 36: 61-66

49 Goudie CA. Production of monosex populations: the channel catfish model. In: Davis KB, Simco BA. International Fish Physiology Symposium, Vancouver, 1994. 150-155

50 Jiang L, Wang ZW, Zhou L, Gui JF. Screening of sex-linked AFLP markers in one cultured population of Channa argus. Acta Hydrobiol Sin, 2013, 37: 1174-1178

51 Gao Z, Wang H P, Wallat G, Yao H, Rapp D, Bryant PO, MacDon- 
ald R, Wang WM. Gonadal sex differentiation in the bluegill sunfish Lepomis macrochirus and its relation to fish size and age. Aquacult Res, 2009, 294: 138-146

52 Walker SPW, Ryen CA, McCormick MI. Rapid larval growth predisposes sex change and sexual size dimorphism in a protogynous hermaphrodite, Parapercis snyderi Jordan \& Starks 1905. J Fish Biol, 2007, 71: 1347-1357

53 Farley JH, Eveson JP, Davis TL, Andamari R, Proctor CH, Nugraha $\mathrm{B}$, Davies CR. Demographic structure, sex ratio and growth rates of southern bluefin tuna (Thunnus maccoyii) on the spawning ground. PLoS One, 2014, 9: e96392

54 Zhu BK, Xie CX. A study of feeding, reproduction, age and growth of Dark sleeper Odontobutis obscura in Bao'An lake. Acta Hydrobiol Sin, 1999, 23: 316-323

55 Afeworki Y, Videler JJ, Berhane YH, Bruggemann JH. Seasonal and life-phase related differences in growth in Scarus ferrugineus on a southern Red Sea fringing reef. J Fish Biol, 2014, 84: 1422-1438

56 Wu CJ, Gui JF. Fish Genetics and Breeding Engineering (in Chinese). Shanghai: Shanghai Scientific and Technical Publishers, 1999

57 Yoneda M, Kurita Y, Kitagawa D, Ito M, Tomiyama T, Goto T, Takahashi K. Age validation and growth variability of Japanese flounder Paralichthys olivaceus off the Pacific coast of northern Japan. Fisheries Science, 2007, 73: 585-592

58 Fischer AJ, Thompson BA. The age and growth of southern flounder, Paralichthys lethostigma, from Louisiana estuarine and offshore waters. B Mar Sci, 2004, 75: 63-77

59 Bye VJ, Lincoln RF. Commercial methods for the control of sexual maturation in rainbow trout (Salmo gairdneri R.). Aquaculture, 1986, 57: 299-309

60 Johnstone R, Youngson AF. The progeny of sex-inverted female Atlantic salmon (Salmo salar L.). Aquaculture, 1984, 37: 179-182

61 Saillant E, Fostier A, Menu B, Haffray P,Chatain B. Sexual growth dimorphism in sea bass Dicentrarchus labrax. Aquaculture, 2001, 202: 371-387

62 Headley HC, Lauer TE. Density-dependent growth of yellow perch in southern Lake Michigan, 1984-2004. North Am J Fish Manag, 2008, 28: 57-69

63 Björnsson B. The growth pattern and sexual maturation of Atlantic halibut (Hippoglossus hippoglossus L.) reared in large tanks for 3 years. Aquaculture, 1995, 138: 281-290

64 Hunter GA, Donaldson EM, Stoss J, Baker I. Production of monosex female groups of chinook salmon (Oncorhynchus tshawytscha) by the fertilization of normal ova with sperm from sex-reversed females. Aquaculture, 1983, 33: 355-364

65 Donaldson EM. Manipulation of reproduction in farmed fish. Anim Reprod Sci, 1996, 42: 381-392

66 Chen SL, Li J, Deng SP, Tian YS, Wang QY, Zhuang ZM, Sha ZX, $\mathrm{Xu}$ JY. Isolation of female-specific AFLP markers and molecular identification of genetic sex in half-smooth tongue sole (Cynoglossus semilaevis). Mar Biotechnol (NY), 2007, 9: 273-280

67 Degani G, Tzchori I, Yom-Din S, Golgberg D, Jackson K. Growth differences and growth hormone expression in male and female European eels (Anguilla anguilla (L.)). Gen Comp Endocrinol, 2003, 134: 88-93

68 Wu B, Zhang MZ, Deng SP. Analysis of morphological index and discrimination of male and female Scatophagus argus. J Shanghai Ocean Univ, 2014, 23: 64-69

69 Pongthana N, Penman DJ, Baoprasertkul P, Hussain MG, Islam MS, Powell SF, Mcandrew BJ. Monosex female production in the silver barb (Puntius gonionotus Bleeker). Aquaculture, 1999, 173: 247-256

70 Munday PL, Buston PM, Warner RR. Diversity and flexibility of sex-change strategies in animals. Trends Ecol Evol, 2006, 21: 89-95

71 Rosenthal GG, Evans CS. Female preference for swords in Xiphophorus helleri reflects a bias for large apparent size. Proc Natl Acad Sci USA, 1998, 95: 4431-4436

72 Casalini M, Agbali M, Reichard M, Konecná M, Bryjová A, Smith C. Male dominance, female mate choice, and intersexual conflict in the rose bitterling (Rhodeus ocellatus). Evolution. 2009, 63: 366-376
73 Desjardins JK, Fernald RD. Fish sex: why so diverse? Curr Opin Neurobiol, 2009, 19: 648-653

74 Bonduriansky R, Chenoweth SF. Intralocus sexual conflict. Trends Ecol Evol, 2009, 24: 280-288

75 Parsch J, Ellegren H. The evolutionary causes and consequences of sex-biased gene expression. Nat Rev Genet, 2013, 14: 83-87

76 Williams TM, Carroll SB. Genetic and molecular insights into the development and evolution of sexual dimorphism. Nat Rev Genet, 2009, 10: 797-804

77 Fairbairn DJ, Roff DA. The quantitative genetics of sexual dimorphism: assessing the importance of sex-linkage. Heredity (Edinb), 2006, 97: 319-328

78 Bachtrog D. Y chromosome evolution: emerging insights into processes of Y chromosome degeneration. Nat Rev Genet, 2013, 14: 113-124

79 Dean R, Mank JE. The role of sex chromosomes in sexual dimorphism: discordance between molecular and phenotypic data. J Evol Biol, 2014; 27: 1443-1453

80 Leinonen T, Cano JM, Merilä J. Genetic basis of sexual dimorphism in the threespine stickleback Gasterosteus aculeatus. Heredity, 2011, 106: $218-227$

81 Hyun S. Body size regulation and insulin-like growth factor signaling. Cell Mol Life Sci, 2013, 70: 2351-2365

82 Reindl KM, Sheridan MA. Peripheral regulation of the growth hormone-insulin-like growth factor system in fish and other vertebrates. Comp Biochem Physiol A Mol Integr Physiol, 2012, 163: 231-245

83 Sebag JA, Zhang C, Hinkle PM, Bradshaw AM, Cone RD. Developmental control of the melanocortin-4 receptor by MRAP2 proteins in zebrafish. Science, 2013, 341: 278-281

84 Lampert KP, Schmidt C, Fischer P, Volff JN, Hoffmann C, Muck J, Lohse MJ, Ryan MJ, Schartl M. Determination of onset of sexual maturation and mating behavior by melanocortin receptor 4 polymorphisms. Curr Biol, 2010, 20: 1729-1734

85 Tao W, Yuan J, Zhou L, Sun L, Sun Y, Yang S, Li M, Zeng S, Huang B, Wang D. Characterization of gonadal transcriptomes from Nile tilapia (Oreochromis niloticus) reveals differentially expressed genes. PLoS One, 2013, 8: e63604

86 Jing J, Wu J, Liu W, Xiong S, Ma W, Zhang J, Wang W, Gui JF, Mei J. Sex-biased miRNAs in gonad and their potential roles for testis development in yellow catfish. PLoS One, 2014, 9: e107946

87 Roberts RB, Ser JR, Kocher TD. Sexual conflict resolved by invasion of a novel sex determiner in Lake Malawi cichlid fishes. Science, 2009, 326: 998-1001

88 Kitano J, Ross JA, Mori S, Kume M, Jones FC, Chan YF, Absher DM, Grimwood J, Schmutz J, Myers RM, Kingsley DM, Peichel CL. A role for a neo-sex chromosome in stickleback speciation. Nature, 2009, 461: 1079-1083

89 Volff JN, Nanda I, Schmid M, Schartl M. Governing sex determination in fish: regulatory putsches and ephemeral dictators. Sex Dev, 2007, 1: 85-99

90 Stelkens RB, Wedekind C. Environmental sex reversal, Trojan sex genes, and sex ratio adjustment: conditions and population consequences. Mol Ecol, 2010, 19: 627-646

91 Baroiller JF, D'Cotta H, Saillant E. Environmental effects on fish sex determination and differentiation. Sex Dev, 2009, 3: 118-135

92 Piferrer F, Ribas L, Diaz N. Genomic approaches to study genetic and environmental influences on fish sex determination and differentiation. Mar Biotechnol (NY), 2012, 14: 591-604

93 Eisbrenner WD. Sex determination in Tasmanian Atlantic salmon. Dissertation for Master's degree. British Columbia: Simon Fraser University, 2013

94 Arkhipchuk VV. Role of chromosomal and genome mutations in the evolution of bony fishes. Hydrobiol J, 1995, 31: 55-65

95 Bull JJ. Sex determining mechanisms: an evolutionary perspective. Experientia, 1985, 41: 1285-1296

96 Liew WC, Orban L. Zebrafish sex: a complicated affair. Brief Funct Genomics, 2014, 13: 172-187

97 Liew WC, Bartfai R, Lim Z, Sreenivasan R, Siegfried KR, Orban L. Polygenic sex determination system in zebrafish. PLoS One, 2012, 7: 
e34397

98 Bradley KM, Breyer JP, Melville DB, .Broman KW, Knapik EW, Smith JR An SNP-based linkage map for zebrafish reveals sex determination loci. G3 (Bethesda), 2011, 1: 3-9

99 Ser JR, Roberts RB, Kocher TD. Multiple interacting loci control sex determination in lake Malawi cichlid fish. Evolution, 2010, 64: 486-501

100 Vandeputte M, Dupont-Nivet M, Chavanne H, Chatain B. A polygenic hypothesis for sex determination in the European sea bass $\mathrm{Di}$ centrarchus labrax. Genetics, 2007, 176: 1049-1057

101 Schultheis C, Zhou Q, Froschauer A, Nanda I, Selz Y, Schmidt C, Matschl S, Wenning M, Veith AM, Naciri M, Hanel R, Braasch I, Dettai A, Böhne A, Ozouf-Costaz C, Chilmonczyk S, Ségurens B, Couloux A, Bernard-Samain S, Schmid M, Schartl M, Volff JN. Molecular analysis of the sex-determining region of the platyfish Xiphophorus maculatus. Zebrafish, 2006, 3: 299-309

102 Cioffi MB, Liehr T, Trifonov V, Molina WF, Bertollo LA. Independent sex chromosome evolution in lower vertebrates: a molecular cytogenetic overview in the Erythrinidae fish family. Cytogenet Genome Res, 2013, 141: 186-194

103 Kitano J, Peichel C. Turnover of sex chromosomes and speciation in fishes. Environ Biol Fishes, 2012, 94: 549-558

104 Orban L, Sreenivasan R, Olsson PE. Long and winding roads: testis differentiation in zebrafish. Mol Cell Endocrinol, 2009, 312: 35-41

105 Geffroy B, Guiguen Y, Fostier A, Bardonnet A. New insights regarding gonad development in European eel: evidence for a direct ovarian differentiation. Fish Physiol Biochem, 2013, 39: 1129-1140

106 Shang EH, Yu RM, Wu RS. Hypoxia affects sex differentiation and development, leading to a male-dominated population in zebrafish (Danio rerio). Environ Sci Technol, 2006, 40: 3118-3122

107 Baroiller JF, Guiguen Y, Fostier A. Endocrine and environmental aspects of sex differentiation in fish. Cell Mol Life Sci, 1999, 55: 910-931

108 Ospina-Alvarez N, Piferrer F. Temperature-dependent sex determination in fish revisited: prevalence, a single sex ratio response pattern, and possible effects of climate change. PLoS One, 2008, 3: e2837

109 Pavlidis M, Koumoundouros G, Sterioti A, Somarakis S, Divanach P, Kentouri M. Evidence of temperature-dependent sex determination in the European sea bass (Dicentrarchus labrax L.). J Exp Zool, 2000, 287: $225-232$

110 Zhou L, Gui JF. Molecular mechanisms underlying sex change in hermaphroditic groupers. Fish Physiol Biochem, 2010, 36: 181-193

111 Xia W, Zhou L, Yao B, Li CJ, Gui JF. Differential and spermatogenic cell-specific expression of DMRT1 during sex reversal in protogynous hermaphroditic groupers. Mol Cell Endocrinol, 2007, 263: $156-172$

112 Wang Y, Zhou L, Yao B, Li CJ, Gui JF. Differential expression of thyroid-stimulating hormone beta subunit in gonads during sex reversal of orange-spotted and red-spotted groupers. Mol Cell Endocrinol, 2004, 220: 77-88

113 Yao B, Zhou L, Wang Y, Xia W, Gui JF. Differential expression and dynamic changes of SOX3 during gametogenesis and sex reversal in protogynous hermaphroditic fish. J Exp Zool A Ecol Genet Physiol, 2007, 307: 207-219

114 Huang W, Zhou L, Li Z, Gui JF. Expression pattern, cellular localization and promoter activity analysis of ovarian aromatase (Cyp19ala) in protogynous hermaphrodite red-spotted grouper. Mol Cell Endocrinol, 2009, 307: 224-236

115 Kobayashi T, Kajiura-Kobayashi H, Guan G, Nagahama Y. Sexual dimorphic expression of DMRT1 and Sox $9 a$ during gonadal differentiation and hormone-induced sex reversal in the teleost fish Nile tilapia (Oreochromis niloticus). Dev Dyn, 2008, 237: 297-306

116 Kitano T, Hayashi Y, Shiraishi E, Kamei Y. Estrogen rescues masculinization of genetically female medaka by exposure to cortisol or high temperature. Mol Reprod Dev, 2012, 79: 719-726

117 Sun LN, Jiang XL, Xie QP, Yuan J, Huang BF, Tao WJ, Zhou LY, Nagahama Y, Wang DS. Transdifferentiation of differentiated ovary into functional testis by long term treatment of aromatase inhibitor in Nile tilapia. Endocrinology, 2014, 155: 1476-1488
118 Takatsu K, Miyaoku K, Roy SR, Murono Y, Sago T, Itagaki H, Nakamura M, Tokumoto T. Induction of female-to-male sex change in adult zebrafish by aromatase inhibitor treatment. Sci Rep, 2013, 3: 3400

119 Godwin J. Social determination of sex in reef fishes. Semin Cell Dev Biol, 2009, 20: 264-270

120 Munday PL, Wilson WJ, Warner RR. A social basis for the development of primary males in a sex-changing fish. Proc Biol Sci, 2006, 273: 2845-2851

121 Sinclair AH, Berta P, Palmer MS, Hawkins JR, Griffiths BL, Smith MJ, Foster JW, Frischauf AM, Lovell-Badge R, Goodfellow PN. A gene from the human sex-determining region encodes a protein with homology to a conserved DNA-binding motif. Nature, 1990, 346: 240-244

122 Hiramatsu R, Matoba S, Kanai-Azuma M, Tsunekawa N, Katoh-Fukui Y, Kurohmaru M, Morohashi K, Wilhelm D, Koopman $\mathrm{P}$, Kanai Y. A critical time window of Sry action in gonadal sex determination in mice. Development, 2009, 136: 129-138

123 Matsuda M, Nagahama Y, Shinomiya A, Sato T, Matsuda C, Kobayashi T, Morrey CE, Shibata N, Asakawa S, Shimizu N, Hori H, Hamaguchi S, Sakaizumi M. DMY is a Y-specific DM-domain gene required for male development in the medaka fish. Nature, 2002, 417: 559-563

124 Myosho T, Otake H, Masuyama H, Matsuda M, Kuroki Y, Fujiyama A, Naruse K, Hamaguchi S, Sakaizumi M. Tracing the emergence of a novel sex-determining gene in medaka, Oryzias luzonensis. Genetics, 2012, 191: 163-170

125 Takehana Y, Matsuda M, Myosho T, Suster ML, Kawakami K, Shin-I T, Kohara Y, Kuroki Y, Toyoda A, Fujiyama A, Hamaguchi S, Sakaizumi M, Naruse K. Co-option of Sox3 as the male-determining factor on the $\mathrm{Y}$ chromosome in the fish Oryzias dancena. Nat Commun, 2014, 5: 4157

126 Kamiya T, Kai W, Tasumi S, Oka A, Matsunaga T, Mizuno N, Fujita M, Suetake H, Suzuki S, Hosoya S, Tohari S, Brenner S, Miyadai T, Venkatesh B, Suzuki Y, Kikuchi K. A trans-species missense SNP in Amhr2 is associated with sex determination in the tiger pufferfish, Takifugu rubripes (fugu). PLoS Genet, 2012, 8: e1002798

127 Hattori RS, Murai Y, Oura M, Masuda S, Majhi SK, Sakamoto T, Fernandino JI, Somoza GM, Yokota M, Strüssmann CA. A Y-linked anti-Mullerian hormone duplication takes over a critical role in sex determination. Proc Natl Acad Sci USA, 2012, 109: 2955-2959

128 Yano A, Guyomard R, Nicol B, Jouanno E, Quillet E, Klopp C, Cabau C, Bouchez O, Fostier A, Guiguen Y. An immune-related gene evolved into the master sex-determining gene in rainbow trout, Oncorhynchus mykiss. Curr Biol, 2012, 22: 1423-1428

129 Matson CK, Zarkower D. Sex and the singular DM domain: insights into sexual regulation, evolution and plasticity. Nat Rev Genet, 2012, 13: $163-174$

130 Zarkower D. DMRT genes in vertebrate gametogenesis. Curr Top Dev Biol, 2013, 102: 327-356

131 Masuyama H, Yamada M, Kamei Y, Fujiwara-Ishikawa T, Todo T, Nagahama Y, Matsuda M. Dmrt1 mutation causes a male-to-female sex reversal after the sex determination by Dmy in the medaka. Chromosome Res, 2012, 20: 163-176

132 Otake H, Shinomiya A, Kawaguchi A, Hamaguchi S, Sakaizumi M. The medaka sex-determining gene $D M Y$ acquired a novel temporal expression pattern after duplication of DMRT1. Genesis, 2008, 46: 719-723

133 Morinaga C, Saito D, Nakamura S, Sasaki T, Asakawa S, Shimizu N, Mitani H, Furutani-Seiki M, Tanaka M, Kondoh H. The hotei mutation of medaka in the anti-Mullerian hormone receptor causes the dysregulation of germ cell and sexual development. Proc Natl Acad Sci USA, 2007, 104: 9691-9696

134 Smith CA, Roeszler KN, Ohnesorg T, Cummins DM, Farlie PG, Doran TJ, Sinclair AH. The avian Z-linked gene DMRT1 is required for male sex determination in the chicken. Nature, 2009, 461: 267-271

135 Yoshimoto S, Okada E, Umemoto H, Tamura K, Uno Y, Nishida-Umehara C, Matsuda Y, Takamatsu N, Shiba T, Ito M. A 
W-linked DM-domain gene, $D M-W$, participates in primary ovary development in Xenopus laevis. Proc Natl Acad Sci USA, 2008, 105: 2469-2474

136 Yoshimoto S, Ikeda N, Izutsu Y, Shiba T, Takamatsu N, Ito M. Opposite roles of DMRT1 and its W-linked paralogue, DM-W, in sexual dimorphism of Xenopus laevis: implications of a ZZ/ZW-type sex-determining system. Development, 2010, 137: 2519-2526

137 Chen S, Zhang G, Shao C, Huang Q, Liu G, Zhang P, Song W, An N, Chalopin D, Volff JN, Hong Y, Li Q, Sha Z, Zhou H, Xie M, Yu Q, Liu Y, Xiang H, Wang N, Wu K, Yang C, Zhou Q, Liao X, Yang L, Hu Q, Zhang J, Meng L, Jin L, Tian Y, Lian J, Yang J, Miao G, Liu S, Liang Z, Yan F, Li Y, Sun B, Zhang H, Zhang J, Zhu Y, Du M, Zhao Y, Schartl M, Tang Q, Wang J. Whole-genome sequence of a flatfish provides insights into ZW sex chromosome evolution and adaptation to a benthic lifestyle. Nat Genet, 2014, 46: 253-260

138 Shao C, Li Q, Chen S, Zhang P, Lian J, Hu Q, Sun B, Jin L, Liu S, Wang Z, Zhao H, Jin Z, Liang Z, Li Y, Zheng Q, Zhang Y, Wang J, Zhang G. Epigenetic modification and inheritance in sexual reversal of fish. Genome Res, 2014, 24: 604-615

139 Graves JA. The epigenetic sole of sex and dosage compensation. Nat Genet, 2014, 46: 215-217

140 Graves JA. Weird animal genomes and the evolution of sex and sex chromosomes. Annu Rev Genet, 2008, 42: 565-586

141 Graves JA. Avian sex, sex chromosomes, and dosage compensation in the age of genomics. Chromosome Res, 2014, 22: 45-57

142 Martínez P, Bouza C, Hermida M, Fernández J, Toro MA, Vera M, Pardo B, Millán A, Fernández C, Vilas R, Viñas A, Sánchez L, Felip A, Piferrer F, Ferreiro I, Cabaleiro S. Identification of the major sex-determining region of turbot (Scophthalmus maximus). Genetics, 2009, 183: 1443-1452

143 Shirak A, Seroussi E, Cnaani A, Howe AE, Domokhovsky R, Zilberman N, Kocher TD, Hulata G, Ron M. Amh and Dmrta2 genes map to tilapia (Oreochromis spp.) linkage group 23 within quantitative trait locus regions for sex determination. Genetics, 2006, 174: 1573-1581

$144 \mathrm{Xu} \mathrm{S}$, Xia W, Zohar Y, Gui JF. Zebrafish dmrta2 regulates the expression of $\operatorname{cdkn} 2 \mathrm{c}$ in spermatogenesis in the adult testis. Biol Reprod, 2013, 88: 14

145 Meyer A, Schartl M. Gene and genome duplications in vertebrates: the one-to-four (-to-eight in fish) rule and the evolution of novel gene functions. Curr Opin Cell Biol, 1999, 11: 699-704

146 Liu S, Li Z, Gui JF. Fish-specific duplicated dmrt2b contributes to a divergent function through Hedgehog pathway and maintains left-right asymmetry establishment function. PLoS One, 2009, 4: e7261

147 Guo B, Zou M, Wagner A. Pervasive indels and their evolutionary dynamics after the fish-specific genome duplication. Mol Biol Evol, 2012, 29: 3005-3022

148 Yano A, Nicol B, Jouanno E, Quillet E, Fostier A, Guyomard R, Guiguen Y. The sexually dimorphic on the Y-chromosome gene ( $s d Y)$ is a conserved male-specific Y-chromosome sequence in many salmonids. Evol Appl, 2013, 6: 486-496

149 Schartl M. Sex chromosome evolution in non-mammalian vertebrates. Curr Opin Genet Dev, 2004, 14: 634-641

150 Nakamura $M$. The mechanism of sex determination in vertebrates: Are sex steroids the key-factor? J Exp Zool A Ecol Genet Physiol, 2010, 313: 381-398

151 Angelopoulou R, Lavranos G, Manolakou P. Sex determination strategies in 2012: towards a common regulatory model? Reprod Biol Endocrinol, 2012, 10: 13

152 Morohashi K, Baba T, Tanaka M. Steroid hormones and the development of reproductive organs. Sex Dev, 2013, 7: 61-79

153 Herpin A, Adolfi MC, Nicol B, Hinzmann M, Schmidt C, Klughammer J, Engel M, Tanaka M, Guiguen Y, Schartl M. Divergent expression regulation of gonad development genes in medaka shows incomplete conservation of the downstream regulatory network of vertebrate sex determination. Mol Biol Evol, 2013, 30: 2328-2346

154 Siegfried KR. In search of determinants: gene expression during gonadal sex differentiation. J Fish Biol, 2010, 76: 1879-1902

155 Trukhina AV, Lukina NA, Wackerow-Kouzova ND, Smirnov AF. The variety of vertebrate mechanisms of sex determination. Biomed Res Int, 2013, 587460

156 Navarro-Martín L, Viñas J, Ribas L, Díaz N, Gutiérrez A, Di Croce L, Piferrer F. DNA methylation of the gonadal aromatase (cyp19a) promoter is involved in temperature-dependent sex ratio shifts in the European sea bass. PLoS Genet, 2011, 7: e1002447

157 Zhang Y, Zhang S, Liu Z, Zhang L, Zhang W. Epigenetic modifications during sex change repress gonadotropin stimulation of cyp19ala in a teleost ricefield eel (Monopterus albus). Endocrinology, 2013, 154: 2881-2890

158 Cnaani A, Levavi-Sivan B. Sexual development in fish, practical applications for aquaculture. Sex Dev, 2009, 3: 164-175

159 Weber GM, Lee CS. Current and future assisted reproductive technologies for fish species. Adv Exp Med Biol, 2014, 752: 33-76

160 Liu SJ. Distant hybridization leads to different ploidy fishes. Sci China Life Sci, 2010, 53: 416-425

161 Zhang Z, Chen J, Li L, Tao M, Zhang C, Qin Q, Xiao J, Liu Y, Liu S. Research advances in animal distant hybridization. Sci China Life Sci, 2014, 57: 889-902

162 Hickling CF. The Malacca tilapia hybrids. J Genet, 1960, 57: 1-10

163 Wohlfarth GW, Hulata G, Halevy A. Growth, survival and sex ratio of some tilapia species and interspecific hybrids. In: Rosenthal $\mathrm{H}$, Sarig S, eds. Research in Modern Aquaculture. Bredene: European Aquaculture Society Special Publication, 1990, 11: 87-101

164 Wohlfarth GW. The unexploited potential of tilapia hybrids in aquaculture. Aquac Res, 1994, 25: 781-788

165 Yang H, Wu TT, Xia DQ. Breeding effect comparison of three kinds of Xiaao hybird tilapia (in Chinese). Sci Fish Farm, 2005, 3: 18

166 Wolters WR, DeMay R. Production characteristics of striped bass $\times$ white bass and striped bass $\times$ yellow bass hybrids. J World Aquacult Soc, 1996, 27: 202-207

167 Bartley DM, Rana K, Immink AJ. The use of inter-specific hybrids in aquaculture and fisheries. Rev Fish Biol Fish, 2000, 10: 325-337

168 Yamamoto E. Studies on sex-manipulation and production of cloned populations in hirame, Paralichthys olivaceus (Temminck et Schlegel). Aquaculture, 1999, 173: 235-246

169 Kato K, Murata O, Yamamoto S, Miyashita S, Kumai H. Viability, growth and external morphology of meiotic-and mitotic-gynogenetic diploids in red sea bream, Pagrus major. J Appl Ichthyol, 2001, 17: 97-103

170 Francescon A, Libertini A, Bertotto D, Barbaro A. Shock timing in mitogynogenesis and tetraploidization of the European sea bass Dicentrarchus labrax. Aquaculture, 2004, 236: 201-209

171 Ji XS, Chen SL, Yang JF, Ma HY, Jiang YL. Artificial gynogenesis and assessment of homozygosity in meiotic gynogens of spotted halibut (Verasper variegatus). Aquacult Int, 2010, 18: 1151-1161

172 Chen SL, Ji XS, Shao CW, Li WL, Yang JF, Liang Z, Liao XL, Xu $\mathrm{GB}, \mathrm{Xu} \mathrm{Y}$, Song WT. Induction of mitogynogenetic diploids and identification of WW super-female using sex-specific SSR markers in half-smooth tongue sole (Cynoglossus semilaevis). Mar Biotechnol (NY), 2012, 14: 120-128

173 Liu YX, Wang GX, Liu Y, Hou JL, Wang YF, Si F, Sun ZH, Zhang XY, Liu HJ. Genetic verification of doubled haploid Japanese flounder, Paralichthys olivaceus by genotyping telomeric microsatellite loci. Aquaculture, 2012, 324-325: 60-63

174 Liu YX, Wang GX, Liu Y, Hou JL, Wang YF, Si F, Sun ZH, Zhang XY, Liu HJ. Production and verification of heterozygous clones in Japanese flounder, Paralichthys olivaceus by microsatellite marker. Afr J Biotechnol, 2011, 10: 17088-17094

175 Liu YX, Han HZ, Wang QL, Jiang L, Wang SL, Zhang XY, Liu Y, Wang YF, Liu YJ, Liu HJ. Choice of microsatellite markers for identifying homozygosity of mitotic gynogenetic diploids in Japanese flounder Paralichthys olivaceus. J Fish Biol, 2013, 82: 588-599

176 Hubbs C, Drewry GE. Occurrence and morphology of a phenotypic male of a gynogenetic fish. Science, 1959, 129: 1227-1229

177 Nanda I, Schlupp I, Lamatsch DK, Lampert KP, Schmid M, Schartl M. Stable inheritance of host species-derived microchromosomes in 
the gynogenetic fish Poecilia formosa. Genetics, 2007, 177: 917-926

178 Liu S, Qin Q, Wang Y, Zhang H, Zhao R, Zhang C, Wang J, Li W, Chen L, Xiao J, Luo K, Tao M, Duan W, Liu Y. Evidence for the formation of the male gynogenetic fish. Mar Biotechnol (NY), 2010, 12: $160-172$

179 Shen Z, Wang H. Molecular players involved in temperature-dependent sex determination and sex differentiation in Teleost fish. Genet Select Evol, 2014, 46: 26

180 Dan C, Mei J, Wang D, Gui JF. Genetic differentiation and efficient sex-specific marker development of a pair of $\mathrm{Y}$ - and $\mathrm{X}$-linked markers in yellow catfish. Int J Biol Sci, 2013, 9: 1043-1049

181 Ninwichian P, Peatman E, Perera D, Liu S, Kucuktas H, Dunham R, Liu Z. Identification of a sex-linked marker for channel catfish. Anim Genet, 2012, 43: 476-477

182 Kovács B, Egedi S, Bártfai R, Orbán L. Male-specific DNA markers from African catfish (Clarias gariepinus). Genetica, 2000, 110: 267-276

183 Felip A, Young WP, Wheeler PA, Thorgaard GH. An AFLP-based approach for the identification of sex-linked markers in rainbow trout (Oncorhynchus mykiss). Aquaculture, 2005, 247: 35-43

184 Koshimizu E, Strüssmann CA, Okamoto N, Fukuda H, Sakamoto T. Construction of a genetic map and development of DNA markers linked to the sex-determining locus in the Patagonian pejerrey (Odontesthes hatcheri). Mar Biotechnol (NY), 2010, 12: 8-13

185 Olmstead AW, Villeneuve DL, Ankley GT, Cavallin JE, Lindberg-Livingston A, Wehmas LC, Degitz SJ. A method for the determination of genetic sex in the fathead minnow, Pimephales promelas, to support testing of endocrine-active chemicals. Environ Sci Technol, 2011, 45: 3090-3095

186 Shikano T, Herczeg G, Merila J. Molecular sexing and population genetic inference using a sex-linked microsatellite marker in the nine-spined stickleback (Pungitius pungitius). BMC Res Notes, 2011, 4: 119

187 Chen J, Wang Y, Yue Y, Xia X, Du Q, Chang Z. A novel male-specific DNA sequence in the common carp, Cyprinus carpio. Mol Cell Probes, 2009, 23: 235-239

188 Lee BY, Coutanceau JP, Ozouf-Costaz C, D'Cotta H, Baroiller JF, Kocher TD. Genetic and physical mapping of sex-linked AFLP markers in Nile tilapia (Oreochromis niloticus). Mar Biotechnol (NY), 2011, 13: 557-562

189 Sun YL, Jiang DN, Zeng S, Hu CJ, Ye K, Yang C, Yang SJ, Li MH, Wang DS. Screening and characterization of sex-linked DNA markers and marker-assisted selection in the Nile tilapia (Oreochromis niloticus). Aquaculture, 2014, 433: 19-27

190 Vale L, Dieguez R, Sánchez L, Martínez P, Viñas A. A sex-associated sequence identified by RAPD screening in gynogenetic individuals of turbot (Scophthalmus maximus). Mol Biol Rep, 2014, 41: 1501-1509
191 Viñas A, Taboada X, Vale L, Robledo D, Hermida M, Vera M, Martínez P. Mapping of DNA sex-specific markers and genes related to sex differentiation in turbot (Scophthalmus maximus). Mar Biotechnol (NY), 2012, 14: 655-663

192 Ma HY, Chen SL, Yang JF, Ji XS, Chen SQ, Tian YS, Bi JZ. Isolation of sex-specific AFLP markers in Spotted Halibut (Verasper variegatus). Environ Biol Fish, 2010, 88: 9-14

193 Galindo HM, Loher T, Hauser L. Genetic sex identification and the potential evolution of sex determination in Pacific halibut (Hippoglossus stenolepis). Mar Biotechnol (NY), 2011, 13: 1027-1037

194 Fuji K, Yoshida K, Hattori K, Ozaki A, Araki K, Okauchi M, Kubota S, Okamoto N, Sakamoto T. Identification of the sex-linked locus in yellowtail, Seriola quinqueradiata. Aquaculture, 2010, 308: S51-55

$195 \mathrm{Xu}$ D, Lou B, Xu H, Li S, Geng Z. Isolation and characterization of male-specific DNA markers in the rock bream Oplegnathus fasciatus. Mar Biotechnol (NY), 2013, 15: 221-229

196 da Silva EM, Wong MS, Martins C, Wasko AP. Screening and characterization of sex-specific DNA fragments in the freshwater fish matrincha, Brycon amazonicus (Teleostei: Characiformes: Characidae). Fish Physiol Biochem, 2012, 38: 1487-1496

197 Piferrer F, Donaldson EM. Uptake and clearance of exogenous estradiol-17 $\beta$ and testosterone during the early development of coho salmon (Oncorhynchus kisutch), including eggs, alevins and fry. Fish Physiol Biochem, 1994, 13: 219-232

198 Wu QJ, Ye YZ, Chen RD, Tong JG. The production of pure line Red Carp 8305 and its biological characteristics (in Chinese). Oceanol Limnol Sin, 1991, 22: 295-300

199 Luo K, Xiao J, Liu S, Wang J, He W, Hu J, Qin Q, Zhang C, Tao M, Liu Y. Massive production of all-female diploids and triploids in the crucian carp. Int J Biol Sci, 2011, 7: 487-495

200 Liu H, Guan B, Xu J, Hou C, Tian H, Chen H. Genetic manipulation of sex ratio for the large-scale breeding of YY super-male and XY all-male yellow catfish (Pelteobagrus fulvidraco (Richardson)). Mar Biotechnol (NY), 2013, 15: 321-328

201 Bachtrog D, Mank JE, Peichel CL, Kirkpatrick M, Otto SP, Ashman TL, Hahn MW, Kitano J, Mayrose I, Ming R, Perrin N, Ross L, Valenzuela N, Vamosi JC. Sex determination: why so many ways of doing it? PLoS Biol, 2014, 12: e1001899

202 Jao LE, Wente SR, Chen W. Efficient multiplex biallelic zebrafish genome editing using a CRISPR nuclease system. Proc Natl Acad Sci USA, 2013, 110: 13904-13909

203 Li M, Yang H, Zhao J, Fang L, Shi H, Li M, Sun Y, Zhang X, Jiang D, Zhou L, Wang D. Efficient and heritable gene targeting in tilapia by CRISPR/Cas9. Genetics, 2014, 197: 591-599

204 Zhang LL, Zhou Q. CRISPR/Cas technology: a revolutionary approach for genome engineering. Sci China Life Sci, 2014, 57: 639-640

Open Access This article is distributed under the terms of the Creative Commons Attribution License which permits any use, distribution, and reproduction in any medium, provided the original author(s) and source are credited. 